\title{
RANCANG BANGUN ALAT PENCAMPUR BAHAN ES KRIM BERBASIS ARDUINO MEGA2560
}

\author{
Mochamad Fajar Wicaksono' ${ }^{1}$, Afan Rahman ${ }^{2)}$ \\ 1) 2) Program Studi Teknik Komputer, Fakultas Teknik dan Ilmu Komputer, Universitas Komputer Indonesia \\ e-mail: ${ }^{1)}$ mfajarw@email.unikom.ac.id, ${ }^{2)}$ afanrahman15@gmail.com
}

\begin{abstract}
The purpose of this study is to facilitate the process of making ice cream for the entrepreneurs home industry. The Arduino Mega2560 is used as the main brain of the system that was created. Arduino Mega2560 will check 5 ice cream material containers using 5 ultrasonic sensors. The process of mixing the ingredients for ice cream begins with waiting input from users regarding cream, milk, and flavorings. In this tool, there are 3 choices of flavors. The next step is to open a valve that uses a solenoid valve to release ice cream material, drive motor DC to move the container and weigh it using the Load Cell sensor. The final stage is Arduino Mega2560 which activates a mixer to mix all ingredients. From the test results, this tool has worked well where this tool can mix the ingredients with success rate of ultrasonic sensors by 90\%, scales with load cells by $92 \%$, the process of controlling the solenoid valve and mixer by $100 \%$.
\end{abstract}

Keywords: Ice cream, Arduino Mega2560, Ultrasonic, Load cell, Solenoid valve

\section{PENDAHULUAN}

Saat ini banyak dari usaha UKM sudah menggunakan bantuan teknologi agar proses produksi dapat terkontrol dan memudahkan para pelaku UKM terkait efektivitas dan efisiensinya. Proses pembuatan es krim membutuhkan takaran yang baik. Oleh karena itu dibutuhkan alat untuk untuk mengatasi dan membantu proses pembuatannya. Pada penelitian ini dibuat alat pencampur bahan es krim otomatis berbasis Arduino Mega2560 yang bertujua untuk memudahkan proses pembuatan es krim untuk pelaku industri UKM. Arduino Mega2560 digunakan sebagai otak utama dari sistem yan dibuat. Arduino Mega2560 akan memeriksa keberadaan bahan krim pada 5 wadah dengan menggunakan 5 buah sensor ultrasonik. Proses pencampuran bahan es krim di mulai dengan menunggu input takaran dari pengguna terkait krim, susu dan perasa. Pada alat ini terdapat 3 pilihan rasa. Proses selanjutnya adalah pembukaan katup yang menggunakan solenoid valve untuk menjatuhkan bahan ke wadah dan menimbang setiap bahan dengan menggunakan sensor Load Cell. Tahap akhir adalah Arduino Mega2560 akan mengaktifkan mixer untuk mencampur semua bahan. Dengan adanya alat ini diharapkan mampu membantu para pelaku usaha khususnya UKM untuk mencampur bahan es krim dan meminimalkan tingkat kesalahan takaran karena human error.

\section{METODE PENELITIAN}

Terdapat beberapa tahap terkait proses pembuatan alat yang dilakukan pada penelitian ini, yaitu pembuatan diagram blok terkait perancangan perangkat keras dan perancangan perangkat lunak. Gambar 1 menunjukkan rancangan diagram blok dari sistem.

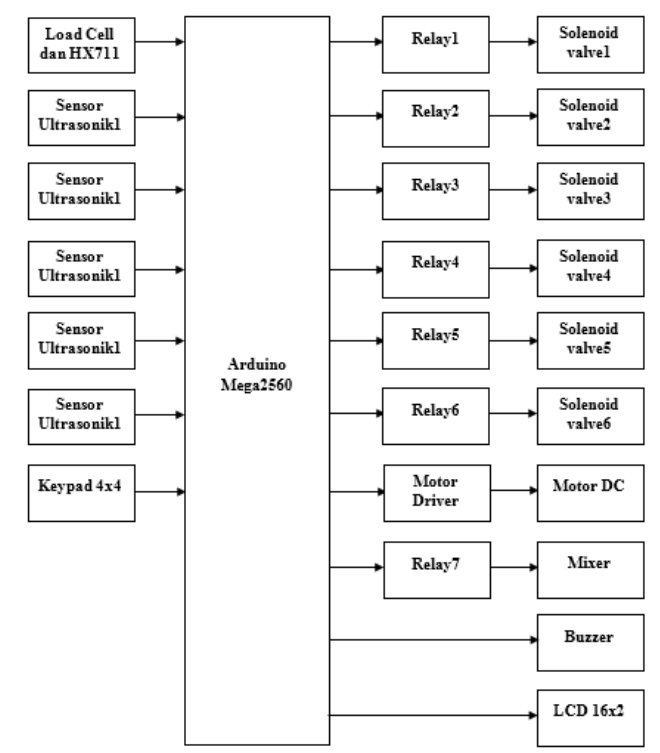

Gambar 1. Diagram Blok

Berikut ini fungsi beserta keterangan dari setiap bagian diagram blok:

\section{Arduino Mega2560}

Arduino Mega2560 adalah sebuah platform fisik yang bersifat open source (Saefullah dkk, 2017). Board ini dilengkapi dengan kristal $16 \mathrm{MHz}, 54$ pin digital, 16 pin analog, tombol reset. UART 
sebanyak 4 pasang, USB, heade ICSP (Dessai dkk, 2017). Board ini kompatibel dengan shield yang didesain untuk Arduino Duemilanove atau Diecimilia (Indraja dkk, 2017). Pada penelitian ini, board ini sebagai otak utama dari sistem yang akan mengolah data dari sensor ultrsonik, load cell dan hx711, kemudian untuk mengatur aktivasi solenoid valve, buzzer, kendali motor DC dan mixer. Bentuk fisik dari Arduino Mega ditunjukkan pada gambar 2 .

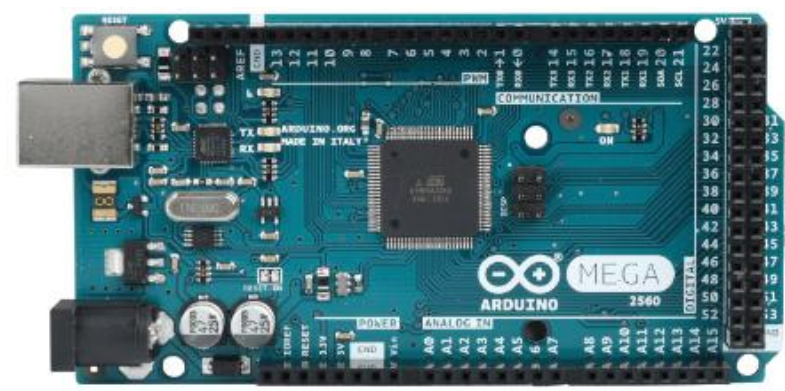

Gambar 2. Arduino Mega2560

\section{Sensor Ultrasonik $\mathbf{1 - 5}$}

Pada penelitian ini digunakan modul sensor ultrasonic HC-SR04. Modul ini mampu mengukur jarak antara $2 \mathrm{~cm}$ sampai dengan $400 \mathrm{~cm}$ dimana akurasinya mencapai $3 \mathrm{~mm}$ (Wicaksono M F \& Hidayat, 2017). Pada penelitian ini sensor ultrasonic HC-SR04 digunakan untuk membaca keberadaan bahan es krim (susu, perasa, krim dan perasa). Bentuk fisik modul sensor ultrasonic HC-SR04 ditunjukkan pada gambar 3 .

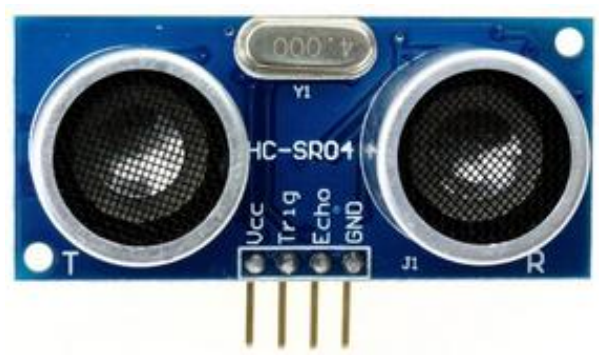

Gambar 3. Ultrasonik HC-SR-04

\section{Load Cell dan HX711}

Load cel adalah sebuah komponen utama pada timbangan digital. Load cell ini terdiri dari jembatan wheatstone, beberapa konduktor dan strain gauge. HX711 adalah modul penguat dan digunakan untuk mengkonversi sinyal analog menjadi sinyal digital (Wahyudi dkk, 2017). Pada penelitian ini sensor load cell digunakan untuk menimbang bahan es krim yang dijatuhkan ke dalam wadah penampung. Bentuk fisik sensor load cell dan HX711 ditunjukkan pada gambar 4 .

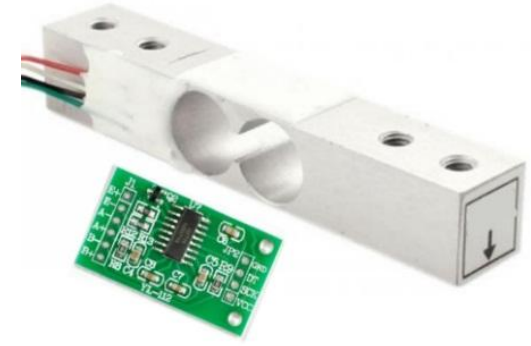

\section{Gambar 4. Load Cell dan HX711}

\section{Solenoid Valve 1-6}

Solenoid valve adalah sebuah alat yang mengubah energi listrik menjadi energi mekanik yang digunakan untuk mengatur katup (Al-Yemni dkk, 2018). Pada penelitian ini solenoid valve 1-6 digunakan untuk mengatur katup 1 sampai dengan katup 6 yang akan mengatur jatuhnya bahan es krim ke wadah dan timbangan. Bentuk fisik solenoid valve ditunjukkan pada gambar 5 .

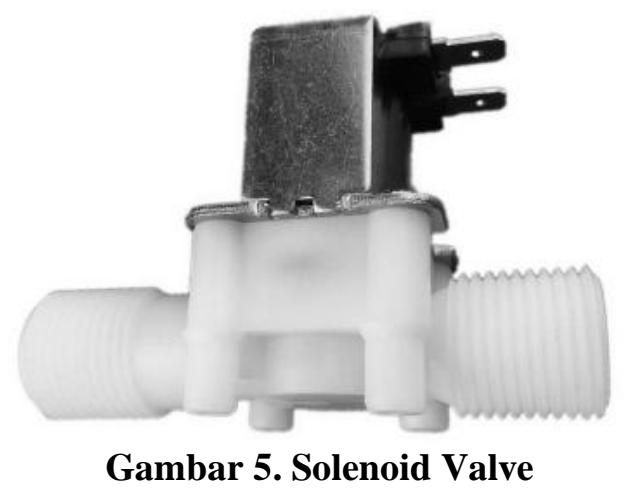

\section{Motor DC}

Motor DC terdiri dari stator dan rotor. Motor DC memerlukan suplai tegangan pada stator untuk diubah menjadi energi mekanik (Waroh, 2014). Pada penelitian ini motor DC digunakan sebagai penggerak timbangan. Bentuk fisik motor DC ditunjukkan pada gambar 6. 


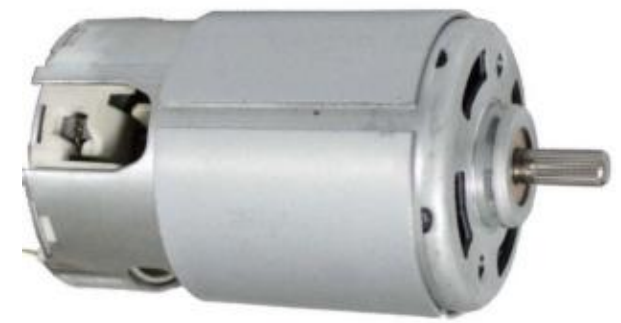

Gambar 6. Motor DC

\section{Relay 1-7}

Relay merupakan saklar elektrik dimana relay ini bekerja dengan daya yang relative kecil namun mampu mengendalikan sesuatu yang membutuhkan daya yang besar (Wicaksono M F, 2017). Pada penelitian ini relay digunakan untuk aktivasi setiap solenoid valve yang dikontrol oleh Arduino Mega2560. Bentuk fisik modul relay yang digunakan ditunjukkan pada gambar 7.

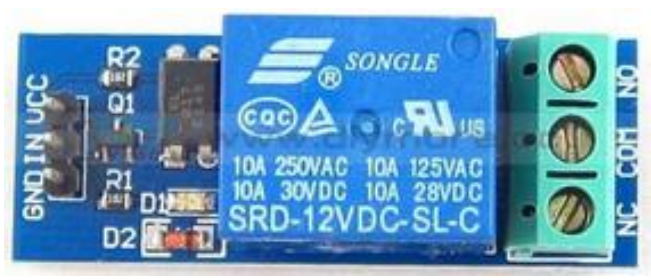

\section{Gambar 7. Modul Relay}

\section{Driver Motor L298N}

Driver motor L298N komponen lektronik yang digunakan untuk mengatur arah putaran motor DC. Satu buah L2986N dapat digunakan untuk mengatur arah putaran 2 motor DC (Adriansyah dkk, 2013). Pada penelitian ini driver motor L298N digunakan untuk me-drive motor DC yang pergerakannya diatur oleh Arduino Mega2560. Bentuk fisik modul L298N yang digunakan ditunjukkan pada gambar 8 .

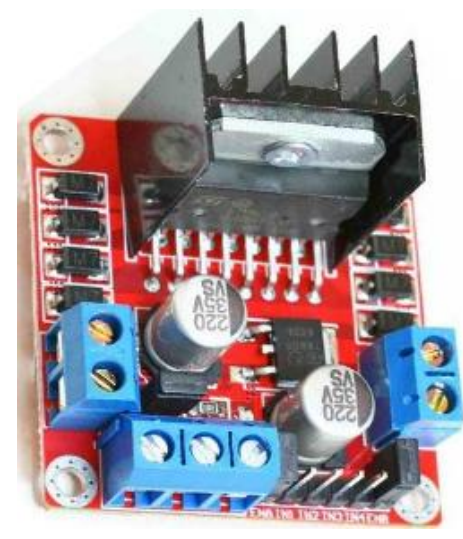

Gambar 8. Modul L298N

\section{LCD 16x2}

LCD atau Liquid Crystal Display merupakan komponen yang berfungsi untuk menampilkan karakter atau huruf (Sinaulan dkk, 2015). Pada penelitian ini LCD 16x2 digunakan sebagai penampil informasi terkait takaran yang akan dimasukkan oleh pengguna. Bentuk fisik modul LCD 16x2 yang digunakan ditunjukkan pada gambar 9.

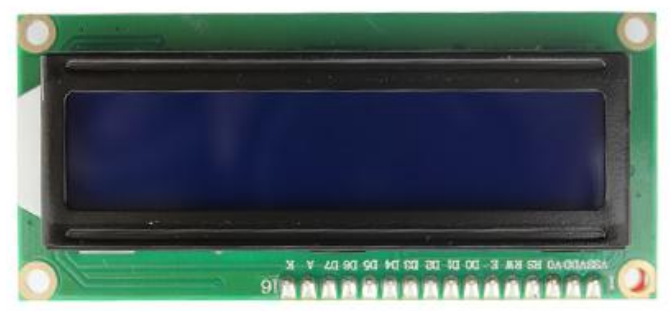

Gambar 9. LCD 16x2

\section{Keypad 4x4}

Digunakan untuk sebagai input terkait pemilihan rasa dan takaran. Bentuk keypad 4x4yang digunakan ditunjukkan pada gambar 10. 


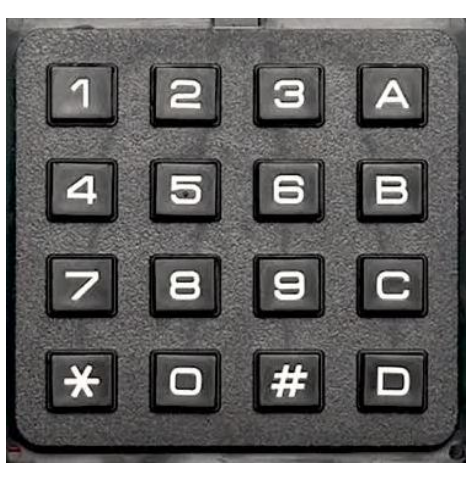

\section{Gambar 10. Keypad 4x4}

\section{Buzzer}

Digunakan untuk mengingatkan pengguna ketika salah satu bahan es krim yang terdapat pada wadah penampung habis.

\section{Mixer}

Digunakan untuk mengaduk bahan es krim.

Bagian selanjutnya adalah bagian perancangan perangka lunak yang ditunjukkan dalam bentuk diagram alir. Gambar 11 menunjukkan perancangan diagram alir dari sistem yang dibuat.

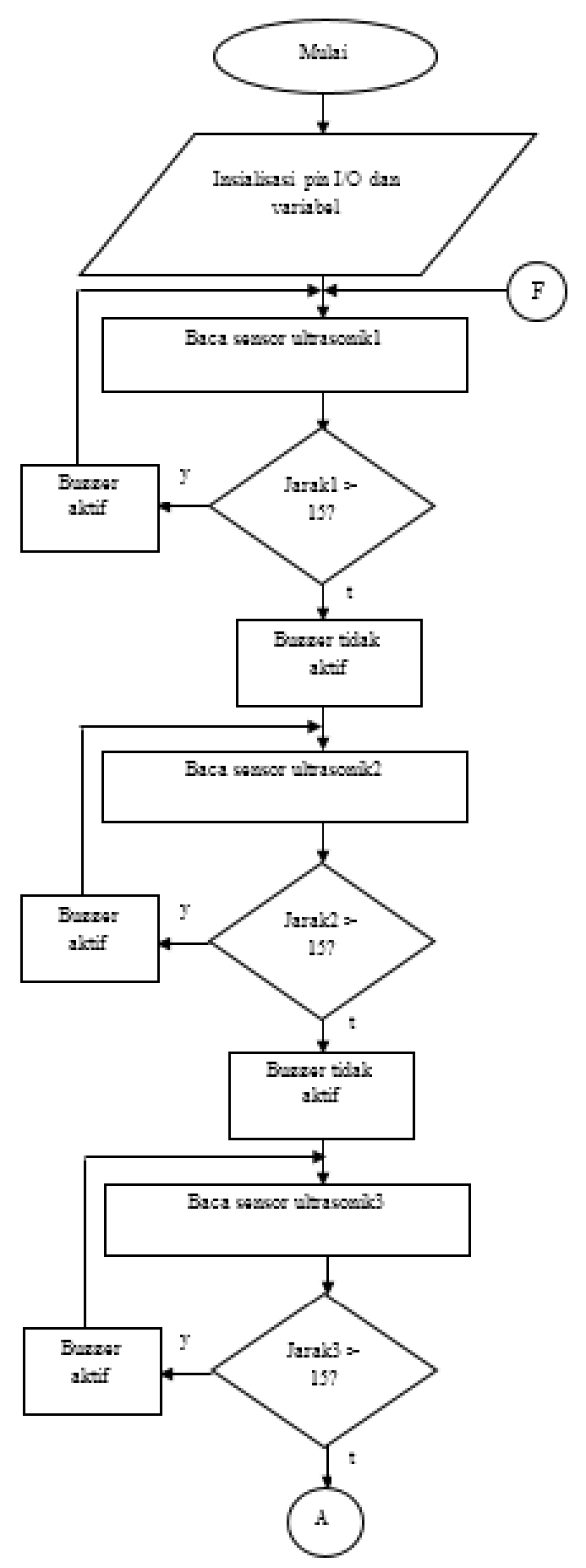

Gambar 11. Diagram alir sistem 


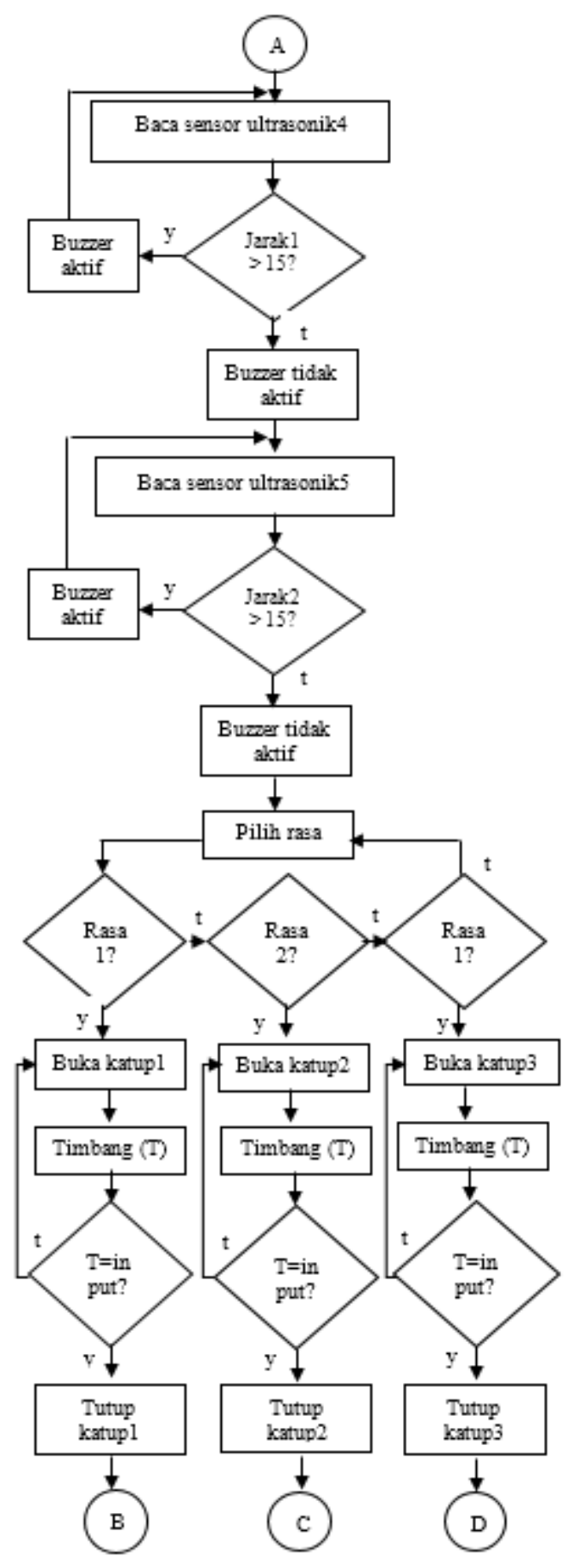

Gambar 11. Lanjutan

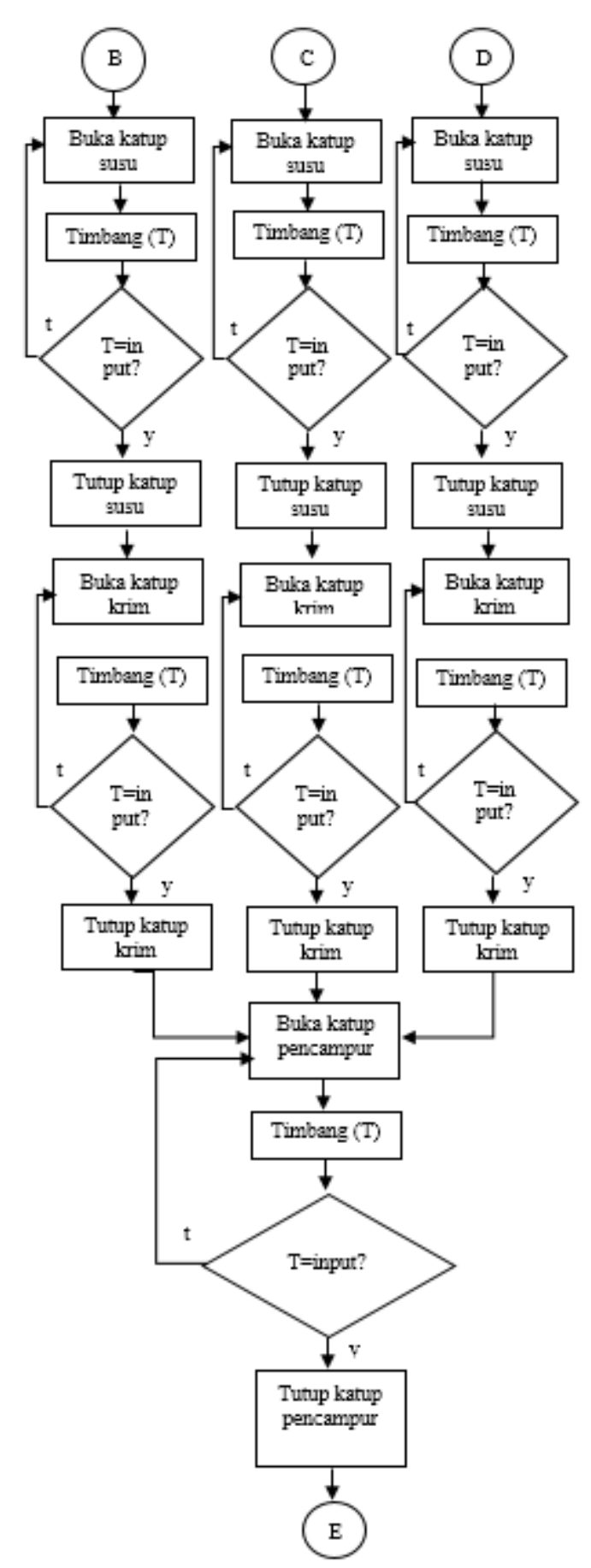

Gambar 11. Lanjutan

Computer Science | Industrial Engineering | Mechanic Engineering | Civil Engineering 


\section{HASIL DAN PEMBAHASAN}

Pengujian yang dilakukan meliputi pengujian fungsi input dari keypad dan output LCD, pengujian timbangan (load cell), pengujian pembacaan keberadaan bahan es krim, dan pengujian solenoid valve. Hasil pengujian pembacaan jarak terkait keberadaan bahan es krim dengan menggunakan sensor ultrasonic HC-SR04 dan aktivasi buzzer ditunjukkan pada tabel 1 .

Tabel 1. Pengujian sensor ultrasonik

\begin{tabular}{|c|c|c|c|c|c|}
\hline \multicolumn{5}{|c|}{ Sensor Utrasonik HC-SR-04 } & \multirow[t]{2}{*}{ Buzzer } \\
\hline 1 & 2 & 3 & 4 & 5 & \\
\hline $\mathrm{x}$ & $\sqrt{ }$ & $\sqrt{ }$ & $\sqrt{ }$ & $\sqrt{ }$ & Berbunyi \\
\hline$\sqrt{ }$ & $\mathrm{x}$ & $\sqrt{ }$ & $\sqrt{ }$ & $\sqrt{ }$ & Berbunyi \\
\hline$\sqrt{ }$ & $\sqrt{ }$ & $\mathrm{x}$ & $\sqrt{ }$ & $\sqrt{ }$ & Berbunyi \\
\hline$\sqrt{ }$ & $\sqrt{ }$ & $\sqrt{ }$ & $\mathrm{x}$ & $\sqrt{ }$ & Berbunyi \\
\hline$\sqrt{ }$ & $\sqrt{ }$ & $\sqrt{ }$ & $\sqrt{ }$ & $\mathrm{x}$ & Berbunyi \\
\hline $\mathrm{x}$ & $\mathrm{x}$ & $\mathrm{x}$ & $\mathrm{x}$ & $\mathrm{x}$ & Berbunyi \\
\hline$\sqrt{ }$ & $\sqrt{ }$ & $\sqrt{ }$ & $\sqrt{ }$ & $\sqrt{ }$ & Tidak Aktif \\
\hline
\end{tabular}

Keterangan:

$\checkmark$ : bahan es krim terdeteksi pada wadah $\mathrm{x}$ : bahan es krim habis

Hasil pengujian terkait keberadaan bahan es krim dengan menggunakan sensor ultrasonik ini berhasil $100 \%$. Hasil pengujian input pada keypad 4x4 dan tampilan pada LCD ditunjukkan pada tabel 2 ..

Tabel 2. Pengujian keypad $4 \times 4$ dan LCD

\begin{tabular}{|c|c|c|c|c|c|c|c|}
\hline Key & LCD & \multicolumn{5}{|c|}{ Pengujian } & Persentase \\
\hline & & 1 & 2 & 3 & 4 & 5 & \\
\hline 1 & Rasa 1 & $\sqrt{ }$ & $\sqrt{ }$ & $\sqrt{ }$ & $\sqrt{ }$ & $\sqrt{ }$ & $100 \%$ \\
\hline 2 & Rasa 2 & $\sqrt{ }$ & $\sqrt{ }$ & $\sqrt{ }$ & $\sqrt{ }$ & $\sqrt{ }$ & $100 \%$ \\
\hline 3 & Rasa 3 & $\sqrt{ }$ & $\sqrt{ }$ & $\sqrt{ }$ & $\sqrt{ }$ & $\sqrt{ }$ & $100 \%$ \\
\hline A & $\begin{array}{c}\text { Input } \\
\text { takaran } \\
\text { krim }= \\
50 \mathrm{~g}\end{array}$ & $\sqrt{ }$ & $\sqrt{ }$ & $\sqrt{ }$ & $\sqrt{ }$ & $\sqrt{ }$ & $100 \%$ \\
\hline B & $\begin{array}{c}\text { Input } \\
\text { takaran } \\
\text { susu }= \\
50 \mathrm{~g}\end{array}$ & $\sqrt{ }$ & $\sqrt{ }$ & $\sqrt{ }$ & $\sqrt{ }$ & $\sqrt{ }$ & $100 \%$ \\
\hline $\mathrm{C}$ & $\begin{array}{l}\text { Input } \\
\text { takaran }\end{array}$ & $\sqrt{ }$ & $\sqrt{ }$ & $\sqrt{ }$ & $\sqrt{ }$ & $\sqrt{ }$ & $100 \%$ \\
\hline
\end{tabular}

\begin{tabular}{|c|c|c|c|c|c|c|c|}
\hline & $\begin{array}{c}\text { perasa } \\
25 \mathrm{~g}\end{array}$ & & & & & & \\
\hline $\mathrm{D}$ & Proses & $\sqrt{ }$ & $\sqrt{ }$ & $\sqrt{ }$ & $\sqrt{ }$ & $\sqrt{ }$ & $100 \%$ \\
\hline$\#$ & $\begin{array}{c}\text { Lihat } \\
\text { data }\end{array}$ & $\sqrt{ }$ & $\sqrt{ }$ & $\sqrt{ }$ & $\sqrt{ }$ & $\sqrt{ }$ & $100 \%$ \\
\hline$*$ & $\begin{array}{c}\text { Reset } \\
\text { data }\end{array}$ & $\sqrt{ }$ & $\sqrt{ }$ & $\sqrt{ }$ & $\sqrt{ }$ & $\sqrt{ }$ & $100 \%$ \\
\hline
\end{tabular}

Hasil pengujian terhadap fungsi dari keypad dan tampilan pada LCD ini berhasil 100\%. Pengujian selanjutnya adalah pengujian pengukuran berat denga menggunakan load cell dimana hasilnya dibandingkan dengan timbangan digital yang sudah terkalibrasi. Tabel 3 menunjukkan hasil pengujian load cell.

Tabel 3. Pengujian Load Cell

\begin{tabular}{|l|l|c|c|c|}
\hline $\begin{array}{l}\text { N } \\
\text { o }\end{array}$ & \multicolumn{1}{|c|}{ Benda } & $\begin{array}{c}\text { Load } \\
\text { Cell } \\
\text { (gram } \\
\text { ) }\end{array}$ & $\begin{array}{c}\text { Timbanga } \\
\text { n Digital } \\
\text { (gram) }\end{array}$ & $\begin{array}{c}\text { Ero } \\
\mathbf{r} \\
(\%)\end{array}$ \\
\hline 1 & $\begin{array}{l}\text { Handphon } \\
\text { e xxx }\end{array}$ & 145 & 146 & 0,7 \\
\hline 2 & $\begin{array}{l}\text { Handphon } \\
\text { e xxx }\end{array}$ & 145 & 146 & 0,7 \\
\hline 3 & $\begin{array}{l}\text { Handphon } \\
\text { e xxx }\end{array}$ & 141 & 146 & 3,5 \\
\hline 4 & $\begin{array}{l}\text { Handphon } \\
\text { e xxx }\end{array}$ & 146 & 146 & 0 \\
\hline 5 & $\begin{array}{l}\text { Handphon } \\
\text { e xxx }\end{array}$ & 144 & 146 & 0,4 \\
\hline 6 & $\begin{array}{l}\text { Susu } \\
125 m l\end{array}$ & 137 & 138 & 0,8 \\
\hline 7 & $\begin{array}{l}\text { Susu } \\
125 m l\end{array}$ & 137 & 138 & 0,8 \\
\hline 8 & $\begin{array}{l}\text { Susu } \\
125 m l\end{array}$ & 128 & 138 & 8 \\
\hline 9 & $\begin{array}{l}\text { Susu } \\
125 m l\end{array}$ & 137 & 138 & 0,8 \\
\hline 10 & $\begin{array}{l}\text { Susu } \\
125 m l\end{array}$ & 131 & 138 & 6 \\
\hline
\end{tabular}

Dari hasil pengujian dapat disimpulkan bahwa timbangan yang digunakan pada sistem ini memiliki error terbesar sebesar 8\%. Pengujian terkait pengontrolan solenoid valve ditunjukkan pada tabel 4.

Tabel 1. Pengujian solenoid valve 


\begin{tabular}{|c|c|c|c|c|c|c|}
\hline \multirow{2}{*}{ Logika } & \multicolumn{5}{|c|}{ Solenoid valve } & \multirow{2}{*}{ Persentase } \\
\cline { 2 - 6 } & $\mathbf{1}$ & $\mathbf{2}$ & $\mathbf{3}$ & $\mathbf{4}$ & $\mathbf{5}$ & \\
\hline 1 & $\sqrt{ }$ & $\sqrt{ }$ & $\sqrt{ }$ & $\sqrt{ }$ & $\sqrt{ }$ & $100 \%$ \\
\hline 1 & $\sqrt{ }$ & $\sqrt{ }$ & $\sqrt{ }$ & $\sqrt{ }$ & $\sqrt{ }$ & $100 \%$ \\
\hline 1 & $\sqrt{ }$ & $\sqrt{ }$ & $\sqrt{ }$ & $\sqrt{ }$ & $\sqrt{ }$ & $100 \%$ \\
\hline 1 & $\sqrt{ }$ & $\sqrt{ }$ & $\sqrt{ }$ & $\sqrt{ }$ & $\sqrt{ }$ & $100 \%$ \\
\hline 1 & $\sqrt{ }$ & $\sqrt{ }$ & $\sqrt{ }$ & $\sqrt{ }$ & $\sqrt{ }$ & $100 \%$ \\
\hline 0 & $\mathrm{x}$ & $\mathrm{x}$ & $\mathrm{x}$ & $\mathrm{x}$ & $\mathrm{x}$ & $100 \%$ \\
\hline 0 & $\mathrm{x}$ & $\mathrm{x}$ & $\mathrm{x}$ & $\mathrm{x}$ & $\mathrm{x}$ & $100 \%$ \\
\hline 0 & $\mathrm{x}$ & $\mathrm{x}$ & $\mathrm{x}$ & $\mathrm{x}$ & $\mathrm{x}$ & $100 \%$ \\
\hline 0 & $\mathrm{x}$ & $\mathrm{x}$ & $\mathrm{x}$ & $\mathrm{x}$ & $\mathrm{x}$ & $100 \%$ \\
\hline 0 & $\mathrm{x}$ & $\mathrm{x}$ & $\mathrm{x}$ & $\mathrm{x}$ & $\mathrm{x}$ & $100 \%$ \\
\hline
\end{tabular}

Dari hasi pengujian terlihat bahwa setiap solenoid valve berfungsi dengan baik dengan persentase keberhasilan sebesar $100 \%$.

\section{KESIMPULAN}

Berdasarkan hasil pengujian dapat disimpulkan bahwa alat pencampur bahan es krim berbasis Arduino Mega2560 ini sudah berjalan dengan baik dimana proses pembacaan keberadaan bahan eskrim berhasil $100 \%$, pengujian input takaran dan tampilan LCD berhasil 100\%, pengujian timbangan pada alat memiliki error terbesar $8 \%$ dan pengujian katup solenoid pada setiap solenoid berhasil $100 \%$.

\section{REFERENSI}

Saefullah A., Sunandar E., Rifai M. N. (2017). Prototipe Robot Pengantar Makanan Berbasis Arduino Mega Dengan Interface Web Browser. Jurnal CCIT, Vol.10 No.2 - Agustus 2017, ISSN: 1978 -8282, pp. 269-279.

Dessai D. D, Gonsalves G. B., Luis M. R., Cardoso M. S. (2017). Dark Detector System for Paper Waste Detection. IJSRD (International Journal for Scientific Research \& Development) Vol. 5, Issue 01, ISSN (online): 2321-0613, pp.873875.

Indraja G., Ramesh P., Prasad S.V.S. (2017). Home Security and Safety System Using Arduino Mega 2560 Controller". International Journal of Research, e-ISSN: 2348-6848 p-ISSN: 2348-795X Volume 04 Issue-17 December 2017, pp. 453-458.

Wicaksono M. F., Hidayat. (2017). Mudah Belajar Mikrokontroler Arduino Disertai 23 Proyek, termasuk Proyek Ethernet dan Wireless Client Server. Bandung: Informatika.
Wahyudi, Rahman A, Nawawi M. (2017). Perbandingan Nilai Ukur Sensor Load Cell pada Alat Penyortir Buah Otomatis Terhadap Timbangan Manual. Jurnal ELKOMIKA, Vol 5 No. 2, Issue Juli - Desember 2017, p-ISSN: 2338-8323, e-ISSN: 2459-9638.

Al-Yemni A., Al-Balam S., Al-Kulib S., Al-Haija Q. A. (2018) An Arduino Based Smart Faucet Design. Compusoft An International Journal of Advanced Computer Technology. Vol 7 No. 5, Issue May 2018 ISSN: 2320-0790, pp. 27522754.

Waroh,A. P. Y. (2014). Analisa Dan Simulasi Sistem Pengendalian Motor DC. Jurnal Ilmiah Sains. Vol 14, No. 2, Oktober 2014, p-ISSN: 1412-3770, e-ISSN: 2540-9840, pp 80-86.

Wicaksono M. F. (2017). Implementasi Modul Wifi NodeMCU Esp8266 untuk Smart Home. Jurnal Teknik Komputer Unikom - Komputika - Vo. 6, No.1 2017, p-ISSN: 2252-9039, eISSN: 2655-3198, pp 1-6. 